Diabetologia 7, 316-322 (1971)

(C) by Springer-Verlag 1971

\title{
Regulation of Glycerol Kinase by Insulin in Isolated Fat Cells and Liver of Bar Harbor Obese Mice
}

\author{
Th. Koschinsky, F. A. Gries and L. Herberg \\ Second Medical Clinic and Diabetes Research Institute, University of Düsseldorf, Düsseldorf, Germany
}

Received: March 23, 1971; accepted: July 14, 1971

Summary. Glycerol kinase was measured by a modification of the radiochemical enzyme test described by Newsholme and coworkers in isolated epididymal and parametrial fat cells and liver tissue of obese hyperglycaemic Bar Harbor mice (obob) and their lean littermates $\left(\mathrm{ob}^{+} \mathrm{ob}^{+}\right)$. The specific activity of glycerol kinase was independent of age in the control animals. It was about 90 times greater in liver than in fat cells. In obese animals glycerol kinase was dependent on age. Compared with the controls, the activity was significantly increased in fat cells of $2-12$-month old mice and in liver of 5 month old mice. In fat cells of 2-12-month old mice fed ad libitum, glycerol kinase activity was significantly correlated to serum IRI-levels. - Glycerol kinase activity decreased during fasting or experimental insulin deficiency, induced by streptozotocin. It was significantly increased in fat cells and liver by insulin substitution. This insulin effect was suppressed by actinomycin D. - It is concluded that insulin regulates glycerol kinase activity by enzyme induction. - The significance of these results for the adipose tissue metabolism in obob mice is discussed.

Régulation de la glycéro-kinase par l'insuline dans les cellules adipeuses isolées et dans le foie chez les sowis obèses de Bar Harbor.

Résumé. La glycéro-kinase a été mesurée à l'aide du test enzymatique radiochimique modifié de Newsholme et collaborateurs dans les cellules adipeuses isolées de l'épididyme et du parametrium et dans le tissu hépatique chez des souris obèses hyperglycémiques de Bar Harbor (obob) et chez des souris de la même portée et de poids normal $\left(\mathrm{ob}^{+} \mathrm{ob}^{+}\right)$. - L'activité spécifique de la glycérokinase ne dépendait pas de l'âge chez les animaux témoins; elle était environ 90 fois plus grande dans le foie que dans les cellules adipeuses. Chez les animaux obèses, la glycérokinase dépendait de l'âge; par rapport aux animaux témoins, l'activité était nettement augmentée dans les cellules adipeuses des souris de 2 à 12 mois et dans le foie de celles de 5 mois. L'activité enzymatique dans les cellules adipeuses des souris de 2 à 12 mois nourries ad libitum, montrait une corrélation significative avec le taux de l'insuline du sérum. Après carence de nourriture ou réduction du taux d'insuline par la streptozotocine, l'activité de la glycéro-kinase était diminuée. Mais elle était augmentée dans les cellules adipeuses et dans le foie par un traitement substitutif à l'insuline. L'actinomycine D inhibait cet effet de l'insuline. On en conclut que l'insuline règle l'activité de la glycéro-kinase par induction enzymatique. La signification de ces résultats quant au métabolisme du tissu adipeux chez la souris obob est discutée.

Regulierung der Glycerokinase durch Insutin in isolierten Fettzellen und im Lebergewebe von fettsüchtigen Bar Harbor Mäusen.

Zusammenfassung, Glycerokinase wurde mit einer Modifikation des radiochemischen Enzymtests von Newsholme und Mitarb. in isolierten epididymalen und parametranen Fettzellen und im Lebergewebe von fettsüchtigen hyperglykämischen Bar Harbor-Mäusen (obob) und deren normgewichtigen Wurfgeschwistern (ob+ob+) bestimmt. Die spezifische Aktivität der Glycerokinase war bei den Kontrolltieren altersunabhängig; sie war in der Leber etwa $90 \times$ größer als in Fottzellen. Bei den fettsüchtigen Tieren war die GK altersabhängig; sie lag in Fettzellen 2-12 Monate alter Tiere und in der Leber 5 Monate alter Tiere um ein Vielfaches über den Kontrollen. In Fettzellen von 2-12 Monate alten, ad libitum gefütterten Tieren korrelierte die Enzymaktivität signifikant zum Seruminsulinspiegel. - Bei Nahrungskarenz oder bei experimenteller Senkung des Insulinspiegels durch Streptozotocin war die Glycerokinaseaktivität vermindert. Sie wurde durch Insulinsubstitution in vivo gesteigert. Dieser Insulineffekt konnte durch Actinomycin $D$ gehemmt werden. Es wird angenommen, daß Insulin die Glycerokinaseaktivität durch Enzyminduktion reguliert. - Die Bedeutung der Befunde für den Fettgewebsstoffwechsel der obob-Maus wird besprochen.

Key-words: Glycerol kinase, insulin, adipose tissue, liver, ob/ob-mice.
In earlier investigations glycerol kinase (GK, EC 2. 7. 1. 30) had only been demonstrated in liver and kidney; it was not found in adipose tissue of normal animals $[13,21]$. This observation has much influenced the considerations on the regulation of adipose tissue metabolism. Thus it was assumed that the $\alpha$-glycerolphosphate, which is necessary for the synthesis of triglycerides, could only be generated by the degradation of carbohydrates. Furthermore, it was postulated that glycerol, which is liberated during lipolysis, cannot be metabolized by the fat cell and, therefore, has to be released. These assumptions formed the basis for the "balance method" of calculating the rate of lipolysis and re-esterification which has been introduced by Steinberg and Vaughan [18].

During the past years, however, there have been several observations pointing to the existence of glycerol kinase in white adipose tissue, especially in the tissue of hereditary obese mice, but these former investigations were not extended, probably because 
the evidence for the enzyme was mostly indirect or the test difficult to reproduce $[2,11,19]$. In addition, it remained unclear whether the GK was located in the fat cell itself or in the surrounding connective tissue. Recently Newsholme and co-workers [15] have introduced a new radioactive test for GK which has been adapted to isolated fat cells [9]. mates $\left(\mathrm{ob}^{+} \mathrm{ob}^{+}\right)$obtained from the Jackson Laboratories, Maine, U.S.A. The animals, studied without pretreatment and fed ad libitum, are described in Table 1 according to age and number of the groups.

26 obese mice of 5 months of age were treated with $225 \mathrm{mg}$ of streptozotocin per $\mathrm{kg}$ of body weight. Streptozotocin was dissolved in $0.9 \%$ sodium chloride,

Table 1. Body weight (wt; g), blood glucose $(b . g . ; \mathrm{mg} / 100 \mathrm{ml}$ ) and serum insulin $(I R I ; \mu$ units $/ m l)$ of obob mice and their lean littermates $o b^{+} o b^{+}$according to age $($ mean $\pm S . E . M$.

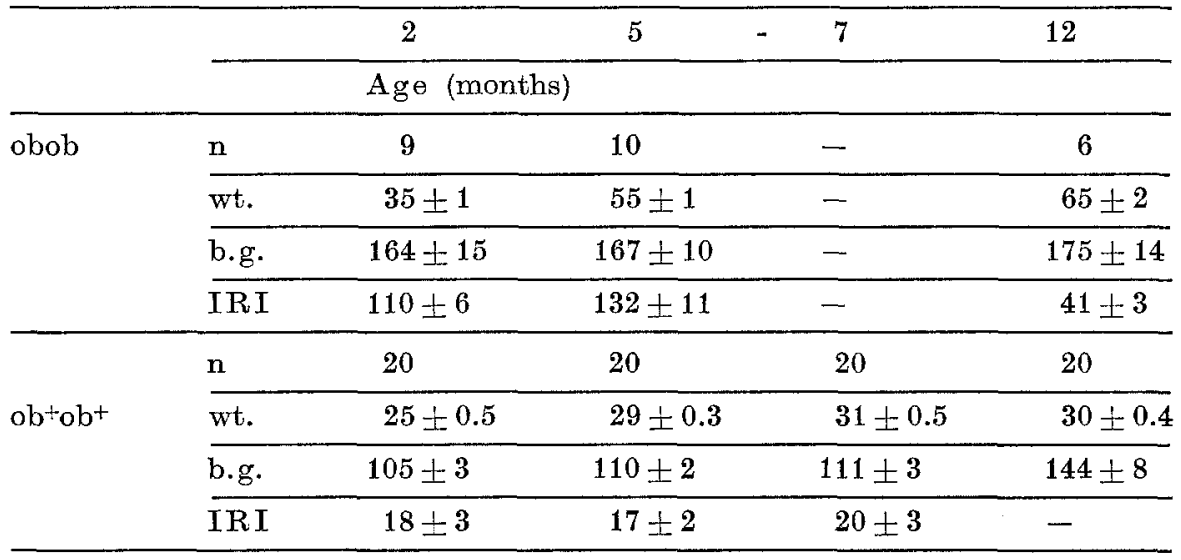

Table 2. Body weight (wt;g), blood glucose $(b . g . ; \mathrm{mg} / 100 \mathrm{ml})$ and serum insulin (IRI; $\mu$ units/ml) of streptozotocin treated obob mice of 5 months of age (mean \pm S.E.M.)

\begin{tabular}{|c|c|c|c|c|c|}
\hline & & pre-treatment & $\begin{array}{l}4 \text { days after } \\
\text { streptozotocin }\end{array}$ & $\begin{array}{l}\text { after treatment } \\
\text { with insulin }\end{array}$ & $\begin{array}{l}\text { after treatment } \\
\text { with insulin and } \\
\text { actinomycin } D\end{array}$ \\
\hline \multirow{3}{*}{$\begin{array}{l}\text { A } \\
\text { streptozotocin } \\
(n=8)\end{array}$} & wt. & $54.3 \pm 1.3$ & $49.8 \pm 1.0$ & \multirow{2}{*}{-} & \multirow{2}{*}{-} \\
\hline & b.g. & $126 \pm 5$ & $459 \pm 12$ & & \\
\hline & IRI & - & $65 \pm 7$ & - & - \\
\hline \multirow{3}{*}{$\begin{array}{l}\text { B } \\
\text { streptozotocin } \\
\text { insulin treated } \\
(n=9)\end{array}$} & wt. & $55.5 \pm 0.9$ & $49.9 \pm 0.8$ & $49.5 \pm 0.8$ & - \\
\hline & b.g. & $142 \pm 8$ & $449 \quad \pm 22$ & $259 \pm 21$ & - \\
\hline & IRI & - & - & $510 \pm 22$ & - \\
\hline \multirow{3}{*}{$\begin{array}{l}\mathrm{C} \\
\text { streptozotocin } \\
\text { insulin and actinomycin D } \\
\text { treated }(n=9)\end{array}$} & wt. & $55.3 \pm 0.4$ & $49.2 \pm 0.4$ & - & $49.3 \pm 0.5$ \\
\hline & b.g. & $149 \pm 8$ & $446 \pm 21$ & - & $240 \pm 20$ \\
\hline & IRI & - & - & - & $489 \pm 19$ \\
\hline
\end{tabular}

The following experiments are concerned with the measurement of GK activity in fat cells and liver of genetically obese mice and their lean litter-mates, the relation of the enzyme activity to insulin secretion and the relation between the GK activity in fat cells and liver.

\section{Materials and Methods}

Animals: The animals studied were C $57 \mathrm{BL} / 6 \mathrm{~J}$ obese hyperglycaemic mice (obob) and their lean litter-
pH 3.5, and injected intraperitoneally. Four days after the injection the animals were taken at random and divided into the following groups (Table 2):

8 animals ("streptozotocin") were studied without further treatment. The remaining 18 animals were treated with insulin according to the following schedule:

At $26 \mathrm{~h}$ prior to decapitation they were injected with 20 units of "Depot-Insulin", at $14 \mathrm{~h}$ with 10 units of "Depot-Insulin" and at $3.5 \mathrm{~h}$ with 5 units of "Alt- 
Insulin" and at $3 \mathrm{~h}$ with 20 units of "Alt-Insulin". Insulin doses were calculated per kg body weight and injected intraperitoneally. Nine of these animals formed the group "streptozotocin - insulin treated", the remaining 9 animals received $10 \mu \mathrm{g}$ of actinomycin $D$ together with each insulin injection and formed the group "streptozotocin, insulin and actinomycin Dtreated". Actinomycin D was dissolved in $0.9 \%$ sodium chloride solution. All of these streptozotocin-treated animals had free access to food and tap water.

The rats studied were male Wistar rats of $200 \mathrm{~g}$ body weight ( $\mathrm{H}$. Müller, Haan, Germany). All animals were killed by decapitation, and blood was collected from the neck.

Methods: The GK assay described by Robinson and Newsholme [16] was adapted to isolated epididymal and parametrial fat cells. Fat cells were isolated with a modification of the method of Rodbell [17]. 500$1000 \mathrm{mg}$ of adipose tissue pieces was incubated in $3 \mathrm{ml}$ of Krebs-Ringer bicarbonate buffer with $1 \mathrm{mg}$ glucose and $3.3 \mathrm{mg}$ collagenase per $\mathrm{ml}$. The incubations were performed in polyethylene vials under an atmosphere of $95 \% \mathrm{O}_{2}$ and $5 \% \mathrm{CO}_{2}$ in a metabolic shaker at $37^{\circ} \mathrm{C}$ for $30 \mathrm{~min}$. The isolated cells were washed [17] with collagenase-free buffer; they were homogenized with the Potter-Elvejhen homogenizer, and centrifuged for $30 \min 100000 \times g$ at $4^{\circ} \mathrm{C}$. The clear middle phase was used for the enzyme test.

The test system contained $100 \mu \mathrm{l}$ of enzyme extract and $50 \mu \mathrm{l}$ of buffer of $\mathrm{pH} 7.5(200 \mathrm{mM}$ Tris, $50 \mathrm{mM}$ 2-mercaptoethanol, $49 \mathrm{mM} \mathrm{NaF}, 10 \mathrm{mM} \mathrm{MgCl}, 2 \mathrm{mM}$ EDTA, $12 \mathrm{mM}$ ATP, $10 \mathrm{mM}$ PEP, $0.3 \mathrm{mg}$ pyruvate kinase $/ \mathrm{ml}$ and $40 \mu \mathrm{Ci}$ glycerol-1 ${ }^{14} \mathrm{C} / \mathrm{ml}$ ). The mixture was incubated for $30 \mathrm{~min}$ at $37^{\circ} \mathrm{C}$ and the reaction was stopped with absolute ethanol. The blank contained the same constituents. However, ethanol was added before the cell extracts in order to prevent any enzyme reaction. Fifty $\mu$ l of the incubate was applied to a DE-81 cellulose filter paper in 3 portions, and the radioactivity measured as described in detail by Robinson and Newsholme [15, 16].

Liver tissue of the same animals was treated in the following manner: The whole liver was obtained immediately after decapitation and frozen in liquid nitrogen. (The enzyme is stable in liquid nitrogen for several days). About $20 \mathrm{mg}$ of the frozen tissue was homogenized and treated as described above. The incubation of the liver extracts was stopped after $5 \mathrm{~min}$, and only $10 \mu \mathrm{l}$ of the incubation mixture was applied to the filter paper and the radioactivity measured.

The radioactivity on the filter papers is given as $\mathrm{dpm}$, and was determined in the Packard Tri-Carb scintillation counter, model 527 . The glycerol phosphate formation was calculated from the specific radioactivity of the glycerol in the reaction mixture. Each value is the mean of two or three determinations. GK activity is indicated as units which are defined as mol glycerol-phosphate production per minute.
The methodological error of the GK assay, as calculated from 10 determinations of a single extract, was $2.5 \%$ of the mean. In order to determine the analytical error of the whole procedure we have examined 10 duplicates of adipose tissue pieces and of liver tissue. The analytical error was calculated according to the formula:

$$
s=\sqrt{\frac{\sum d^{2}}{2 n}}
$$

where d equals the difference between the duplicates and $n$ the number of duplicates. It was $6.3 \%$ of the mean in isolated fat cells and $3.8 \%$ of the mean in liver. Glycerol in the reaction mixture was measured according to Kreutz [10]. Protein was determined according to Lowry, as described by Zak [12, 22]. Blood sugar was measured with the glucose oxidase method, employing the reagent set from Boehringer, Mannheim, Germany. Immunologically reacting insulin (IRI) in serum was determined according to Hales and Randle, method C [4], employing reagents from the Radiochemical Centre, Amersham, England.

Materials: Streptozotocin (10 t 9164-VDV-136/U9889) was obtained from the Upjohn Company, Kalamazoo, U.S.A., Actinomycin D (10 t L 554651-0-10) from Merck, Sharp and Dohme, Rahway, New York, U.S.A. The insulin was received from Hoechst $A G$, Frankfurt/ Main, Germany. Collagenase (3. 4. 4. 1. 9; clostridium histolyticum), obtained from Serva-Entwicklungslabor, Heidelberg, Germany, was $40 \%$ ammonium sulphate precipitate with $150 \mathrm{EU}$ per mg dry weight. Glycerol$1_{1}{ }^{14} \mathrm{C}, 15.4 \mathrm{mCi} / \mathrm{mmol}$ was purchased from the Radiochemical Centre, Amersham, England. According to the manufacturer, radiochemical purity was greater than $99 \%$. There were no impurities by glucose, fructose, glycerolaldehyde or their phosphorylated derivatives.

Statistics: Statistics were calculated on the Olivetti Computor using programeards No. 156 for mean and standard deviations and standard error of the mean, No. 164 for significance according to Student's test and No. 201 for the calculation of correlations.

\section{Results}

GK was demonstrated in extracts of isolated fat cells derived from the epididymal or parametrial fat pad. As expected, it could also be demonstrated in the extracts of liver. The specific activity of GK in liver is more than 10 times higher than that in isolated fat cells (Fig. 1 and 2). No difference in GK activity was observed between male and female mice.

Marked differences could be seen between obob mice and their normal weight litter-mates. In isolated fat cells of lean litter-mates the specific activity $(0.211$ $m \mu U$ per mg protein) was independent of the age of the animals. In isolated fat cells of obese animals the specific GK activity was significantly higher and depended on age and weight of the animals. It was 
highest in animals of 2 to 5 months of age $(2.17 \pm 0.15$ and $2.36 \pm 0.11 \mathrm{~m} \mu \mathrm{U} / \mathrm{mg}$ protein respectively), where it exceeded about 10 -fold that of the lean controls. In obese mice of 12 months of age GK decreased to $0.802 \pm 0.04 \mathrm{muU}$ per $\mathrm{mg}$ protein; however, it was still significantly higher than in the controls.

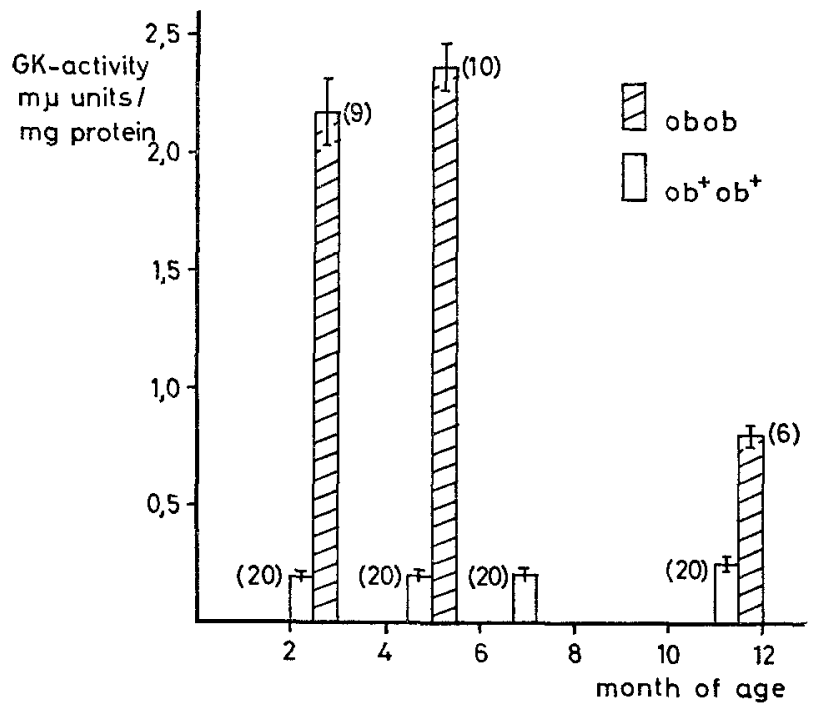

Fig. 1. Age dependence of the specific activity of GK in fat cells of Bar Harbor obese mice (obob) and their lean litter-mates (ob-ob+) fed ad libitum

Number of animals ( ), mean \pm SEM month the liver GK in obese mice was increased twofold over that of the controls.

The GK activity in isolated fat cells (Fig. 3) was significantly correlated to insulin levels of serum obtained from fed obese as well as lean animals. When the animals were fasted for $48 \mathrm{~h}$, GK in isolated fat

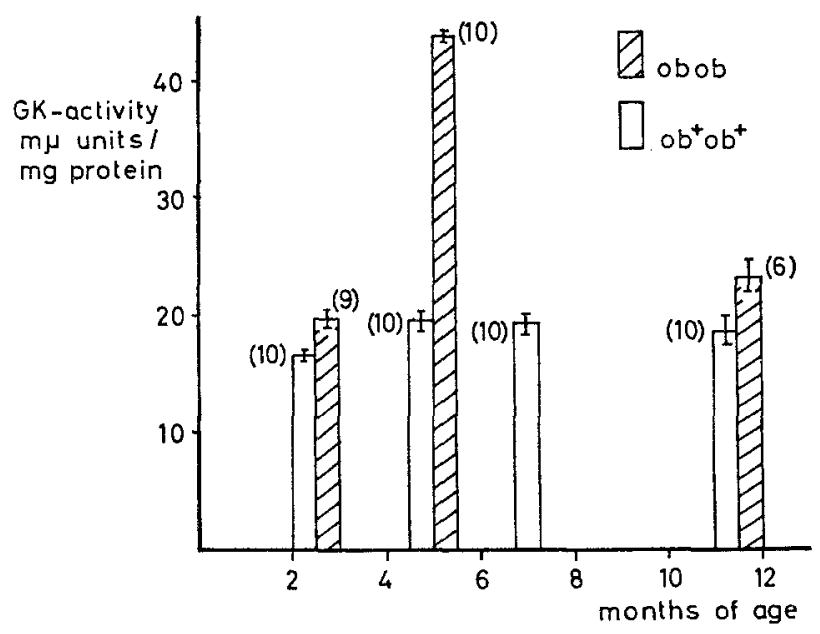

Fig. 2. Age dependence of the specific activity of GK in liver of Bar Harbor obese mice (obob) and their lean litter-mates $\left(\mathrm{ob}^{+} \mathrm{ob}^{+}\right)$fed ad libitum For symbols see legend to Fig. 1

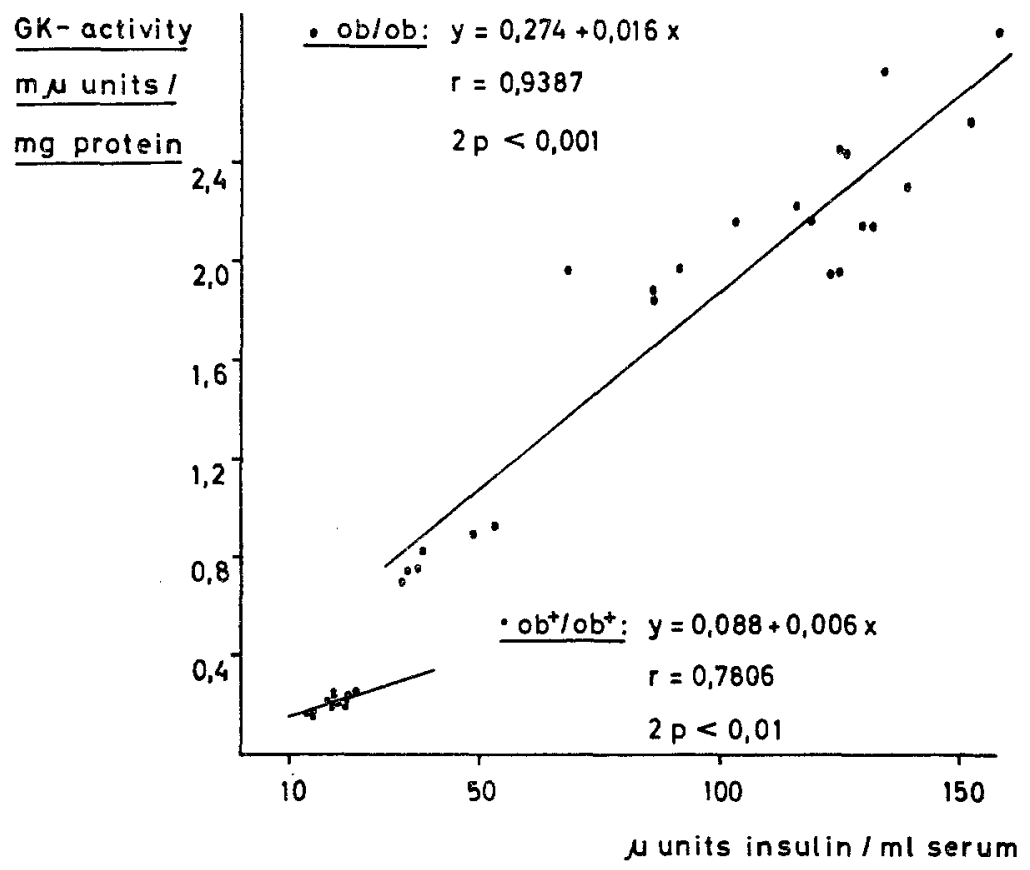

Fig. 3. Correlation between serum IRI $(\mathrm{x})$ and the specific activity of GK (y) in fat cells of Bar Harbor obese mice and their loan litter-mates fod ad libitum

When 2 months old animals were compared, GK in the liver of obese mice was not significantly different from that in lean litter-mates. However, in the 5 th cells was reduced by about $40 \%$ compared with fed controls. Simultaneously, the body weight decreased by 13 to $15 \%$. 
Studies in obese mice of 5 months of age which were insulin deficient after treatment with streptozotocin, are summarized in Table 2 and figures 4 and 5 .

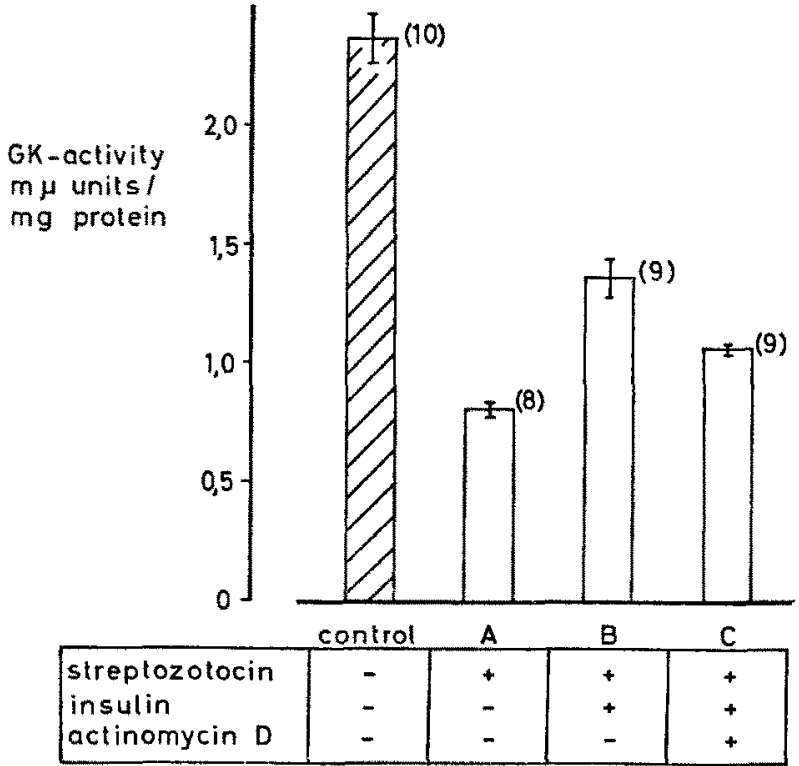

Fig. 4. Specific activity of GK in fat cells of Bar Harbor obese mice (obob) of 5 months of age before and after treatment with streptozotocin with and without insulin and actinomycin $D$

For details compare text.

Number of animals (), mean $\pm \mathrm{SEM}$

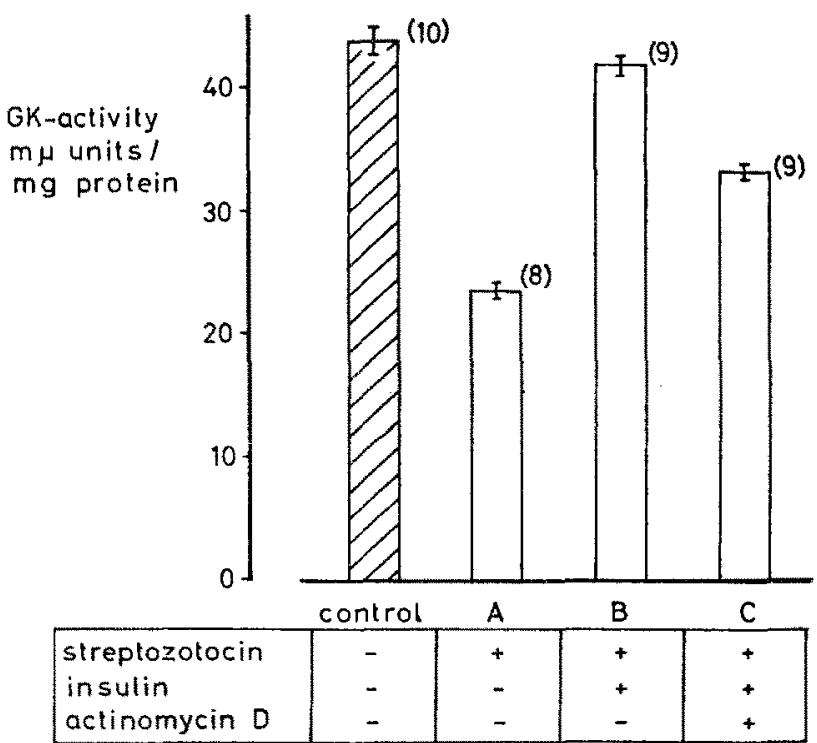

Fig. 5. Specific activity of GK in liver of Bar Harbor obese mice

For animals and symbols see legend to Fig. 4

Four days after the administration of streptozotocin blood sugar in obese mice increased about 3-fold while serum insulin was decreased by $50 \%$. Body weight of all animals decreased simultaneously by about $10 \%$ in spite of free access to food. Half of these animals exhibited a lipaemic turbidity of the blood serum. In these mice GK activity in the fat cells was reduced by $48 \%$ and GK in the liver was reduced by $32 \%$ of the pre-treatment values (group A, table 2 , figures 4 and 5 ). When these animals were treated with insulin for $26 \mathrm{~h}$ (group B, Table 2) the body weight remained constant. The blood sugar decreased by $38 \%$ whilst serum insulin level was elevated 7-fold. In these animals GK activity of the fat cells and the liver was augmented significantly in comparison with that of the non-insulintreated animals. When the "streptozotocin" animals were treated simultaneously with insulin and actinomycin D, there was no difference in the insulin-treated group with respect to body weight, blood sugar and serum insulin. However, the increment in GK activity of the isolated fat cells and liver was almost completely blocked by the addition of actinomycin $\mathrm{D}$. The difference between the animals which were substituted with insulin only and those which were simultaneously treated with insulin and actinomycin $\mathrm{D}$ is significant.

\section{Discussion}

Newsholme and co-workers [16] have shown that GK of muscle and adipose tissue is rapidly destroyed when incubated at room temperature in media of pH 9.6, such as have been used in the test systems employed by former investigators $[1,13,18,21]$. The GK assay used in this study, which is a modification of the test of Newsholme, is performed at a $\mathrm{pH}$ of 7.5 which provides a good stability of the enzyme [16]. With this assay system GK could be demonstrated in isolated fat cells of both normal weight and obese mice. The GK in the lean controls was of the same order of magnitude as that in normal rats and did not change during aging of the animals. By contrast, much higher activities were observed in isolated fat cells of obese mice, and this activity was dependent on the age of the animals.

It is known $[5 \mathrm{a}, 20]$ and confirmed in the present study, that the pathological increase in body weight in obob mice mainly occurs up to the age of 5 months. During this time also high serum insulin levels are observed. After the age of about 7-8 months body weight decreases until death occurs and hyperinsulinaemia concomitantly reduces. By contrast, in lean litter-mates the main increase in body weight occurs up to the age of 2 months; thereafter body weight and serum IRI levels remain constant. These observations are apparently paralleled by the GK activity in adipose tissue. As shown in Fig. 3, there is indeed a strong correlation between postprandial serum IRI and the specific activity of GK in isolated fat cells. It seems possible, therefore, that GK activity in isolated fat cells is regulated by serum insulin levels.

These observations in untreated animals prompted further studies in obese animals made insulin deficient by streptozotocin, which supported the view that 
insulin plays a role in the regulation of GK in adipose tissue. The decrease in serum insulin following streptozotocin resulted in an augmentation of the diabetic syndrome, and was paralleled by the decrease in GK in isolated fat cells. Furthermore, the application of exogenous insulin was able to increase the enzyme activity in isolated fat cells. It could be noted that the serum level of endogenous and exogenous insulin of these animals was higher than before streptozotocin application; however, the insulin levels measured at the time of decapitation do not reflect the mean insulin levels during the $26 \mathrm{~h}$ of insulin therapy, which were probably lower. Furthermore, the duration of an effective increase in serum insulin might have been too short for a complete restoration of the activity. The increment of GK activity by insulin was almost completely blocked by simultaneous application of actinomycin D. Since this agent blocks protein synthesis $[3,14,23]$, it may be assumed that the effect of insulin on GK activity is an enzyme induction rather than an enzyme activation. Our observations on liver GK of obese mice are in agreement with studies by Kampf and co-workers on the liver GK in alloxan-diabetic rats $[7,8]$.

Increased specific activity of GK in obese mice indicates an augmentation of the enzyme in relation to other cell proteins. As determined in preceding experiments (unpublished results), the amount of extractable protein of fat cells of obese mice is on the average at least four times greater than that of lean littermates. Therefore, it is most likely that the difference of the GK activity per fat cell is much greater than the difference in specific activity.

A possible physiological role of the GK in fat cells is the phosphorylation of part of the glycerol which is generated during lipolysis. This seems to be minute in lean litter-mates; however, it may be of major importance in obese mice. It can be calculated from published data of this laboratory, which were obtained from the same strain of mice, that in lean litter-mates GK activity will only be able to phosphorylate about one hundredth of the glycerol which is liberated after stimulation of lipolysis with $10^{-3} \mathrm{M}$ DB-c-AMP. This calculation is consistent with the small incorporation in vitro of added glycerol into fat cell lipids of normal animals $[2,6,11,18]$. Contrary, in obese mice the enzyme activity might theoretically phosphorylate up to one fifth of the liberated glycerol. Therefore, it may be discussed whether in these animals glycerol release is the true measure of lipolysis. If GK plays a role in the regulation of adipose tissue metabolism of obese mice, as postulated earlier by Mayer [13a], one may assume that it facilitates the esterification of fatty acids thus promoting fat deposition. Therefore, the high insulin level in obese mice seems to be a main factor which sustains the overweight by inducing GK activity. It explains the difficulty in reducing the fat mass of obese mice, in spite of the fact that the lipolysis of the single fat cell is raised [5].
The present studies were performed on laboratory animals; however, if the insulin effect on GK activity in adipose tissue is universal, one might expect similar changes in human obesity. This question is subject of a subsequent paper.

Acknowledgements. The skilful assistance of Miss A. Schostek and M. Bergmann is gratefully appreciated. We thank Dr. Dulin, Upjohn Company, for the gift of Streptozotocin and Dr. Hofmann, Merck Sharp \& Dohme, for the gift of Actinomycin D. The work was supported by grants from the Deutsche Forschungsgemeinschaft, Bad Godesberg (Gr. 102/8) and Landesamt für Forschung des Landes Nordrhein-Westfalen, Düsseldorf.

\section{References}

1. Bublitz, C., Kennedy, E.P.: Synthesis of phosphatids in isolated mitochondria: III. The enzymatic phosphorylation of glycerol. J. biol. Chem. 211, 951-961 (1954).

2. Cahill, G.F., Leboeuf, B.: Adipose tissue metabolism. In: "Fat as a tissue". Edit.: Rodahl, K. McGraw-Hill Book Comp. New York 169 - 183 (1964).

3. Goldberg, I.H., Rabinowitz, A., Reich, E.: Basis of actinomycin action I. Proc. nat. Acad. Sci. US 48, 2094-2099 (1962).

4. Hales, C.N., Randle, P.J.: Immunoassay of insulin with insulin-antibody precipitate. Biochem. J. 88, $137-146$ (1963).

5. Herberg, L., Gries, F.A., Hesse-Wortmann, Ch.: Effect of weight and cell size on hormone-induced lipolysis in New Zealand obese mice and American obese hyperglycemic mice. Diabetologia 6, 300-305 (1970).

5a. - Major, E., Hennings, U., Grüneklee, D., Freytag, G., Gries, F.A.: Differences in the development of the obese-hyperglycemic syndrome in obob and NZO. mice. Diabetologia 6, 292-299 (1970).

6. Hubbard, R.W., Vorheis, M.P., Therrioult, D.G.: The incorporation of glycerol into the glycerideglyoerin of fat cells isolated from chronically coldexposed rats. Lipids 5, 114-119 (1970).

7. Kampf, S.C., Seitz, H.J., Tarnowski, W. : Alteration of glycerokinase activity in rat liver in different nutritional and hormonal states. Life Sci. 7, 815-825 (1968).

8. - - Regulation of glycerol metabolism: I. Hormonal and metabolic control of rat liver glycerolkinase activity. Hoppe Seyler Z. Physiol. Chem. 351, $32-40(1970)$.

9. Koschinsky, Th., Gries, F.A., Herberg, L.: Glycerolkinase activity in isolated fat cells of $\mathrm{BHob}$ mice. Horm. Metab. Res. 2, 185-186 (1970).

10. Kreutz, F.H.: Enzymatische Glycerinbestimmung. Klin. Wschr. 40, 362 (1962).

11. Lochaya, S., Hamilton, J.C., Mayer, J.: Lipase and glycerolinase activities in the adipose tissue of obesehyperglycemic mice. Nature 197, 182-183 (1963).

12. Lowry, O.H., Rosebrough, N.J., Farr, A.L., Randall, R.J.: Protein measurement with the folin phenol reagent. J. biol. Chem. 193, 265-275 (1951).

13. Margolis, S., Vaughan, M.: $\alpha$-glycerophosphate synthesis and breakdown in homogenates of adipose tissue. J. biol. Chem. 237, 44-48 (1962)

13a. Mayer, J.: Obesity. Ann. Rev. Med. 14, 111-132 (1963).

14. Merits, I.: Actinomyein inhibition of RNA synthesis in rat liver. Biochem. biophys. Res. Commun. 10, 254-262 (1963).

15. Newsholme, E.A., Robinson, J., Taylor, K.: A radio- 
chemical enzymatic activity assay for glycerolkinase and hexolzinase. Biochim. biophys. Acta 132, 338346 (1967).

16. Robinson, J., Newsholme, E.A.: Glycerolkinase activities in rat heart and adipose tissue. Biochem. J. 104, $2 \mathrm{C}-4 \mathrm{C}$ (1967).

17. Rodbell, M. : Metabolism of isolated fat cells. 1. Effects of hormones on glucose metabolism and lipolysis. J. biol. Chem. 239, 375-380 (1964).

18. Steinberg, D., Vaughan, M.: Release of free fatty acids from adipose tissue in vitro in relation to rates of triglyceride synthesis and degradation. In : Handbook of Physiology, Section 5: Adipose Tissue. Eds.: Renold, A.E., Cahill jr. G.F., American Physiological Society, Washington D.C. 335-347 (1965).

19. Treble, D.M., Mayer, J.: Glycerolkinase activity in white adipose tissue of obese-hyperglycemic mice. Nature 200, 363 (1963).

20. Westman, S.: Development of the obese-hyperglyce- mic syndrome in mice. Diabetologia 4, 141-149 (1968).

21. Wieland, O., Suyter, M.: Glycerokinase: Isolation and properties of the enzyme. Biochem. Z. 329, 320-331 (1957).

22. Zak, B., Cohen, J.: Automatic analysis of tissue culture proteins with stable folin reagents. Clin. Chim. Acta 6, 665-670 (1961).

23. Zillig, W.: Die Wirkung von Antibiotics auf Komponenten und Reaktionen des Protein BiosyntheseApparates. Arch. exp. Path. Pharm. 253, 131-135 (1966).

Dr. Th. Koschinsky

Diabetes-Forschung'sinstitut

Universität Düsseldorf

D-4000 Düsseldorf

Moorenstr. 5

Deutschland 